\title{
SCIENTIFIC REP RTS \\ OPEN Erratum: The role of dung beetles in reducing greenhouse gas emissions from cattle farming
}

Eleanor M. Slade, Terhi Riutta, Tomas Roslin \& Hanna L. Tuomisto

Scientific Reports 6:18140; doi: 10.1038/srep18140; published online 05 January 2016; updated on 08 March 2016

The original version of this Article contained an error in the Abstract.

"These considerations give a new perspective on previous results perspective, and suggest that studies of biotic effects on GHG emissions from dung pats on a global scale are a priority for current research."

now reads:

"These considerations give a new perspective on previous results, and suggest that studies of biotic effects on GHG emissions from dung pats on a global scale are a priority for current research.”

This has now been corrected in the PDF and HTML versions of the Article.

(i) This work is licensed under a Creative Commons Attribution 4.0 International License. The images or other third party material in this article are included in the article's Creative Commons license, unless indicated otherwise in the credit line; if the material is not included under the Creative Commons license, users will need to obtain permission from the license holder to reproduce the material. To view a copy of this license, visit http://creativecommons.org/licenses/by/4.0/ 